\title{
Portuguese state university performance according to students: an efficiency analysis
}

\author{
Desempenho de universidades estaduais portuguesas de acordo com os \\ estudantes: uma análise de eficiência \\ actuación de universidades estatales portuguesas de acuerdo con los \\ estudiantes: un análisis de eficiencia
}

EMERSON WAGNER MAINARDES

HELENA ALVES

MÁRIO RAPOSO

\begin{abstract}
The objective of this research project is to evaluate the performance of Portuguese state universities in accordance with the expectations and satisfactions of their students and through recourse to the DEA methodology and thus representing one of the very few studies analysing university performance based upon student perceptions. According to an output oriented Variable Returns to Scale model, handling the responses returned by 1,669 students, the results demonstrate that faculties generally attain a good relationship between student expectations and their levels of satisfaction. We furthermore conclude that university scale does not guarantee efficiency. Hence, irrespective of size, universities are able to ensure the satisfaction of their students. Finally, the results show that satisfying only certain expectations related to specific aspects does not prove sufficient to guaranteeing overall student satisfaction. The analysis also correspondingly finds that while some decision making units prove efficient in satisfying expectations on specific aspects, they fail to attain such efficiency in the overall perspective of students.
\end{abstract}

Keywords: Data envelopment; higher education; student satisfaction; student expectations

Resumo: O objetivo deste projeto de pesquisa é avaliar o desempenho das universidades estaduais portuguesas de acordo com as expectativas e satisfações de seus alunos e através do recurso à metodologia DEA e, portanto, representar um dos poucos estudos que analisam o desempenho das universidades com base na percepção discente. Os resultados demonstram que as faculdades geralmente alcançam uma boa relação entre as expectativas dos alunos e seus níveis de satisfação, de acordo com uma pesquisa orientada por um modelo de escala com resultados variáveis, baseado em respostas de 1.669 estudantes. Concluímos ainda que a dimensão universitária não garante eficiência. Assim, independentemente de sua dimensão, as universidades são capazes de garantir a satisfação dos seus alunos. Finalmente, os resultados mostram que satisfazer apenas determinadas expectativas relacionadas a aspectos específicos não prova suficiência para garantir a satisfação geral dos alunos. A análise também conclui que, enquanto algumas unidades tomam decisões e mostram eficiência 
em satisfazer expectativas em aspectos específicos, elas falham em atingir esta eficiência na percepção geral dos estudantes.

Palavras-chave: envoltória de dados; ensino superior; satisfação discente; expectativas discente

Resumen: El objetivo de este proyecto de investigación es evaluar la actuación de las universidades estatales portuguesas de acuerdo con las expectativas y satisfacciones de sus alumnos y a través del recurso a la metodología DEA y, por lo tanto, representar uno de los pocos estudios que analisan la actuación de las universidades, basados en la percepción discente. Los resultados demuestran que las facultades generalmente alcanzan una buena relación entre las expectativas de los alumnos y sus niveles de satisfacción, de acuerdo con una investigación orientada por un modelo de escala con resultados variables, basado en respuestas de 1.669 estudiantes. Concluimos, también, que la dimensión universitaria no garantiza eficiencia. Así, independientemente de su dimensión, las universidades son capaces de garantizar la satisfacción de sus alumnos. Finalmente, los resultados muestran que satisfacer solo determinadas expectativas relacionadas a aspectos específicos no prueba suficiencia para garantizar la satisfacción general de los alumnos. El análisis también concluye que, mientras algunas unidades tomam decisiones y muestran eficiencia en satisfacer expectativas en aspectos específicos, ellas fallan al alcanzar esta eficiencia en la percepción general de los estudiantes.

Palabras clave: análisis envolvente de datos; enseñanza superior; satisfacción discente; expectativas discentes

\section{INTRODUCTION}

Satisfaction is a variable that has long been subject to evaluation within organisational environments (Grönroos, 2000). Representing the extent to which the organisation meets the expectations of its consumers or users (Vargo \& Lusch, 2004), satisfaction, especially in service sectors (Grönroos \& Ojasalo, 2004), has proven to be an important factor for measuring the quality of organisational outputs, whether products or services (Anderson \& Fornell, 2000, Alvarez \& Merino, 2003). The advantages of consumer satisfaction are dealt with extensively by the literature. Some of the advantages mentioned are better financial performance, client loyalty, heightened competitiveness, among others (Kotler, 2003, Pitelis, 2009), and all constituting fundamental factors for any organisation.

Satisfaction in higher education has commonly been evaluated in accordance with traditional statistical analytical approaches, such as regression or structural equations in order to guide and orient organisational management decision making processes (Alves \& Raposo, 2007). However, organizational 
efficiency analysis based on stakeholders satisfaction, and applying comparative methods of efficiency, have been rare in the literature. Therefore, the usage of efficiency analysis for organisational performance evaluation from the stakeholder's satisfaction perspective opens up different insights to traditional satisfaction analysis allowing for the comparison of different units measured by the same inputs and outputs. This kind of analysis deploys mathematical tools to comparatively evaluate the results of a group of decision making units (DMU) establishing frontiers of efficiency among the several DMU evaluated (Shaw, 2009). Thus, it defines which DMUs attain better performance levels and therefore should be examples to be followed by the others. Among the mathematical tools more commonly adopted to carry out these analytical processes is Data Envelopment Analysis (DEA).

Therefore, the main goal of this research is to evaluate the performance of Portuguese state universities taking into consideration the expectations and satisfaction levels of their students through recourse to data envelopment analysis.

\section{EFFICIENCY ANALYSIS}

Evaluating the efficiency of DMUs (Decision Making Units) is achievable through recourse to the utilisation of parametric (requiring the parametricisation of the functional relationship between resources consumed and that produced, that is, the same unit of measurement) or non-parametric methodologies (not contemplating the same unit of measurement). An example of the latter method is evaluating the efficiency of a university by its number of students, number of professors, number of publications, and number of patents, among others. All these variables may be measured in different ways but may also be subject to joint analysis through non-parametric techniques (Johnes, 2006).

According to Grönroos \& Ojasalo (2004), services, as is the case with higher education services, due to their inherent nature, require non-parametric efficiency analysis. Many studies (for example, Scheerens, 2000, Johnes, 2006, Youn \& Park, 2009, Kantabutra \& Tang, 2010) approach the analysis of university efficiency through non-parametric measurements even though none of these studies focuses on the student satisfaction perspective. The overwhelming majority of studies on the field of higher education evaluate the efficiency of universities based upon the filling of existing vacancies, student graduates, professors number, revenues obtained, among others and without ever mentioning student perceptions. Grönroos \& Ojasalo (2004) consider the perspective of the service user as fundamental to measuring the efficiency of a service organisation, as is indeed the case with universities. 
According to Cooper, Seiford \& Tone (2000), there has been increasing concern over measuring and comparing the efficiency of organisational units, such as schools, hospitals, stores, bank branches and other similar cases where there is a relatively homogenous group of units. These authors find that the usual measurement of efficiency (linkage between outputs and inputs) very commonly falls short due to the existence of multiple entries and exits with different resources, activities and environmental factors.

DEA emerged out of efforts to resolve this problem. According to Charnes, Cooper \& Rhodes (1978), DEA is a linear programming technique seeking to measure the relative performance of an organisation's units in which the presence of multiple inputs and outputs render comparisons difficult.

DEA may be appropriate for units running different inputs or outputs or when there is a high level of uncertainty or disagreement over the value of some of the entrances and exits (as is the case with individual perceptions). Different to other methodologies, DEA is a frontier searching methodology and not focusing on central trends as is the case with regressions. Due to this facet, DEA proves effective in discovering relationships that remain hidden to other analytical methods given that DEA deals with multiple entrances and exits, contrary to regression that deals only with one output at a time (Sarrico \& Dyson, 2000, Fandel, 2007).

According to Zhu (2009), DEA works as follows: each of the DMUs chosen runs multiple entrances in order to produce multiple exits. Based upon the information existing on entrances and exits, the production possibilities are specified. The range of production possibilities represents all feasible combinations of entrances and exits and may be continuous or discrete. One specific section of the range of production possibilities is called the efficient frontier. Where a DMU is positioned on the efficient frontier, it is termed an efficient unit, where contrary, it is deemed inefficient. DEA provides efficiency indexes and a set of references for inefficient DMUs. The efficiency scores represent an efficiency level for each DMU. The set of references for inefficient units consists of a range of efficient units and determines a virtual target unit on the efficient frontier. Correspondingly, DEA serves to verify the efficiency of a unit and to find a set of references and score the efficiency of inefficient units. Therefore, the DEA technique also offers a point of reference for the improvement of inefficient unit performances and policies designed to ensure higher production results and the reduction of inputs, depending on the respective analytical objective (Johnes, 2006).

From the perspective of Zhu (2009), this type of analysis proves relevant to universities for: allocating resources within the university (rewarding efficient 
over inefficient units); identifying best practices; defining the targets to be achieved by each unit; monitoring changes in efficiency over the course of time; identifying those units worthy of reward for good performance; and the planning of positioning and investment strategies.

\section{METHODOLOGY AND ANALYSIS STRUCTURE}

\subsection{DMU Definition and Selection}

As DMUs, we chose Portuguese state universities with the objective of ascertaining their efficiency level and identifying those with best practices. However, carrying out global analysis of eleven Portuguese state universities would be unlikely to discriminate between them. Therefore, so as to obtain more meaningful results, students were divided up within and between universities by breaking them down into five different faculties based upon their degree of study. With this division, we obtained a total of 55 DMUs (11 x 5), a number capable of returning the highest standard of results. In the end, due to the very low number of respondents, seven DMUs were excluded from analysis, although not compromising the validity of the overall analysis, according to Avkiran's (1999) formula.

\subsection{Selection of Variables}

The literature shows how DEA has been deployed to evaluate higher education systems on numerous occasions (for example, Sarrico \& Dyson, 2000, Johnes, 2006, Youn \& Park, 2009, Kantabutra \& Tang, 2010). Nevertheless, there have been no studies evaluating the efficiency of universities based upon student satisfaction. Furthermore, evaluating DMU efficiency in terms of consumer satisfaction has already been undertaken for other objects of study, such as banks and supermarkets (Cooper, Seiford \& Tone, 2006).

However, in order to analyse satisfaction as a process, it becomes fundamental to understand just which variables influence it. Several researchers (Halstead, Hartman and Schmidt, 1994; Taylor, 1996; Athiyaman, 1997; Eskildsen et al., 1999; Rautopuro \& Vaisanen, 2000; Alves \& Raposo, 2007a; Alves \& Raposo, 2007b) have found that expectations or expectation disconfirmation are variables that play an important role in shaping and forming student satisfaction levels.

The study by Mainardes, Alves and Domingues (2009) verified that the features most valued by students were the level of study requirements, personal 
self-achievement and the university environment. Thus, we adopted the general expectation and satisfaction levels of students, in addition to these three specific factors identified by Mainardes, Alves and Domingues (2009) for this study. Hence, the selected inputs were the average rankings attributed to the DMU for:

- Student expectations as to the level of study requirements, the university environment and personal self-achievement;

- General student expectations in relation to their degree program;

- General student expectations in relation to their university.

The corresponding outputs were the average rankings awarded the DMU for:

- Student satisfaction in relation to the level of study requirement, the university environment and personal self-achievement;

- General student satisfaction in relation to their degree program;

- General student satisfaction in relation to their university.

Finally, in accordance with the choices made, the analysis incorporated a total of five inputs and five outputs. Taking into consideration there were 55 DMUs, we applied the formula defined by Avkiran (1999) to test analytical validity and which mathematically deduced that the result between the number of DMUs multiplied by the number of inputs and outputs should be greater than 1.333 (DMU's / (inputs*outputs)). For the case in question, the result returned was 2.20, which clearly validates the DEA analysis undertaken by this project.

\subsection{Data Collection and choice of model}

Having defined the DMUs, the inputs and the outputs, an online questionnaire was drafted and applied for the specific purpose of obtaining the data necessary for analysis. The questionnaire contained four questions, two relating to expectations (degree and university) and two relating to satisfaction (degree and university). Each question had five response options (Likert scale, see Hair Jr. et al., 2003), corresponding to no expectations through to high expectations and to very dissatisfied through to highly satisfied (in accordance with the question). After these four questions, the student detailed their university, the study program attended and the faculty running the program.

Following a pre-test, the questionnaire was deemed valid and ready for application. The survey was sent out to all students at eleven Portuguese public universities (129,534 students), via email on 29th April 2010. Responses were received from 29th April through to 21st May of the same year. Following that date, we embarked on data evaluation and seeking to identify any bias in the 
answer or failures/difficulties in filling in the duly returned questionnaires. Of the 1,832 questionnaires returned, 1,669 were deemed valid.

Since the objective in this research is to expand satisfaction and not reduce the initial expectations, we opted for the output oriented Variable Returns to Scale model.

\section{DATA ANALYSIS}

The data analysis process designed to evaluate the performance of Portuguese state universities based on the satisfaction of their students was structured as follows: presentation of data for analysis, analysis of DMU efficiency levels taking the expectation and satisfaction levels obtained from student as our inputs and outputs, respectively. This analytical process identified just which DMUs are the most efficient, hence, those at the frontier of relative efficiency (best performance in relation to the other DMUs) thereby portraying the general panorama of the performance of Portuguese state universities in terms of satisfying their students' expectations.

\subsection{Data for Analysis}

As already explained, 55 DMU's were subject to study across five inputs and five outputs. Table 1 presents the data for analysis.

Table 1 - Data for DEA analysis

\begin{tabular}{|c|c|c|c|c|c|c|c|c|c|c|c|}
\hline University & DMU & $\begin{array}{c}\text { Average } \\
\text { Expec. } \\
\text { Deman. } \\
\text { (MEE) }\end{array}$ & $\begin{array}{c}\text { Average } \\
\text { Expec. } \\
\text { Achieve. } \\
\text { (MER) }\end{array}$ & $\begin{array}{c}\text { Average } \\
\text { Expec. } \\
\text { Amb. } \\
\text { (MEA) }\end{array}$ & $\begin{array}{c}\text { Average } \\
\text { Expec. } \\
\text { Degree } \\
\text { (MEC) }\end{array}$ & $\begin{array}{c}\text { Average } \\
\text { Expec. } \\
\text { Univ. } \\
\text { (MEU) }\end{array}$ & $\begin{array}{c}\text { Average } \\
\text { Satis. } \\
\text { Deman. } \\
\text { (MSE) }\end{array}$ & $\begin{array}{c}\text { Average } \\
\text { Satis. } \\
\text { Achieve. } \\
\text { (MSR) }\end{array}$ & $\begin{array}{c}\text { Average } \\
\text { Satisf. } \\
\text { Amb. } \\
\text { (MSA) }\end{array}$ & $\begin{array}{l}\text { Average } \\
\text { Satisf. } \\
\text { Degree } \\
\text { (MSC) }\end{array}$ & $\begin{array}{c}\text { Average } \\
\text { Satisf. } \\
\text { Univ. } \\
\text { (MSU) }\end{array}$ \\
\hline \multirow{5}{*}{$\begin{array}{l}\text { University } \\
\text { of the } \\
\text { Algarve }\end{array}$} & UAlg_CS & 3.95 & 4.18 & 4.23 & 4.14 & 4.18 & 3.82 & 4.00 & 4.36 & 4.00 & 4.05 \\
\hline & UAlg_CM & 3.91 & 4.18 & 4.36 & 3.73 & 3.55 & 3.45 & 3.45 & 3.82 & 3.55 & 3.45 \\
\hline & UAlg_CB & Excl. & -- & -- & -- & -- & -- & -- & -- & -- & -- \\
\hline & UAlg_Eng & 4.00 & 4.13 & 4.07 & 3.80 & 3.87 & 3.67 & 3.87 & 4.40 & 3.80 & 4.13 \\
\hline & UAlg_AL & Excl. & -- & - & - & - & - & -- & -- & -- & -- \\
\hline \multirow{5}{*}{$\begin{array}{l}\text { University } \\
\text { of the } \\
\text { Azores }\end{array}$} & UAc_CS & 3.85 & 4.38 & 4.39 & 3.72 & 3.41 & 3.49 & 3.74 & 3.99 & 3.62 & 3.56 \\
\hline & UAc_CM & 3.68 & 4.27 & 4.36 & 4.05 & 3.59 & 3.86 & 3.91 & 4.09 & 3.95 & 3.27 \\
\hline & UAc_CB & 4.00 & 4.70 & 3.80 & 4.00 & 3.70 & 3.50 & 4.10 & 4.20 & 3.60 & 3.20 \\
\hline & UAc_Eng & 4.07 & 4.25 & 4.50 & 3.93 & 3.46 & 3.39 & 3.50 & 3.57 & 3.50 & 3.21 \\
\hline & UAc_AL & 3.83 & 3.83 & 4.39 & 3.70 & 3.52 & 3.52 & 3.52 & 3.78 & 3.35 & 3.43 \\
\hline
\end{tabular}


Table 1 - Data for DEA analysis

\begin{tabular}{|c|c|c|c|c|c|c|c|c|c|c|c|}
\hline University & DMU & $\begin{array}{l}\text { Average } \\
\text { Expec. } \\
\text { Deman. } \\
\text { (MEE) }\end{array}$ & $\begin{array}{c}\text { Average } \\
\text { Expec. } \\
\text { Achieve. } \\
\text { (MER) }\end{array}$ & $\begin{array}{c}\text { Average } \\
\text { Expec. } \\
\text { Amb. } \\
\text { (MEA) }\end{array}$ & $\begin{array}{l}\text { Average } \\
\text { Expec. } \\
\text { Degree } \\
\text { (MEC) }\end{array}$ & $\begin{array}{l}\text { Average } \\
\text { Expec. } \\
\text { Univ. } \\
\text { (MEU) }\end{array}$ & $\begin{array}{l}\text { Average } \\
\text { Satis. } \\
\text { Deman. } \\
\text { (MSE) }\end{array}$ & $\begin{array}{c}\text { Average } \\
\text { Satis. } \\
\text { Achieve. } \\
\text { (MSR) }\end{array}$ & $\begin{array}{l}\text { Average } \\
\text { Satisf. } \\
\text { Amb. } \\
\text { (MSA) }\end{array}$ & $\begin{array}{l}\text { Average } \\
\text { Satisf. } \\
\text { Degree } \\
\text { (MSC) }\end{array}$ & $\begin{array}{c}\text { Average } \\
\text { Satisf. } \\
\text { Univ. } \\
\text { (MSU) }\end{array}$ \\
\hline \multirow{5}{*}{$\begin{array}{l}\text { University } \\
\text { of Beira } \\
\text { Interior }\end{array}$} & UBI_CS & 4.00 & 4.46 & 4.21 & 3.91 & 3.57 & 3.84 & 4.09 & 4.16 & 4.03 & 3.90 \\
\hline & UBI_CM & 4.25 & 4.81 & 4.81 & 3.81 & 3.19 & 3.94 & 3.94 & 4.19 & 3.88 & 3.94 \\
\hline & UBI_CB & 4.33 & 4.25 & 4.17 & 3.67 & 3.50 & 4.00 & 4.00 & 4.08 & 3.75 & 3.75 \\
\hline & UBI_Eng & 4.00 & 4.20 & 4.42 & 3.94 & 3.40 & 3.40 & 3.46 & 3.96 & 3.42 & 3.16 \\
\hline & UBI_AL & 3.78 & 3.83 & 4.11 & 3.72 & 3.33 & 3.78 & 4.06 & 4.17 & 3.89 & 3.56 \\
\hline \multirow{5}{*}{$\begin{array}{l}\text { University } \\
\text { of } \\
\text { Coimbra }\end{array}$} & UC_CS & 4.44 & 4.20 & 4.20 & 4.04 & 4.04 & 3.44 & 3.72 & 3.92 & 3.08 & 3.32 \\
\hline & UC_CM & 4.50 & 4.75 & 4.25 & 4.00 & 4.00 & 3.75 & 3.50 & 4.25 & 3.33 & 3.58 \\
\hline & UC_CB & 4.24 & 4.64 & 4.52 & 3.76 & 3.84 & 3.84 & 3.68 & 4.20 & 3.72 & 4.08 \\
\hline & UC_Eng & 4.14 & 4.42 & 4.37 & 4.03 & 4.08 & 3.73 & 3.66 & 4.20 & 3.81 & 4.00 \\
\hline & UC_AL & Excl. & - & - & -- & - & - & - & -- & - & - \\
\hline \multirow{5}{*}{$\begin{array}{l}\text { University } \\
\text { of Évora }\end{array}$} & UEvora_CS & 4.11 & 4.47 & 4.31 & 3.71 & 3.82 & 3.64 & 3.96 & 3.96 & 3.67 & 3.42 \\
\hline & UEvora_CM & 4.60 & 4.80 & 4.60 & 4.10 & 3.60 & 3.80 & 4.30 & 4.30 & 4.10 & 3.80 \\
\hline & UEvora_CB & 4.11 & 4.44 & 4.44 & 3.63 & 3.44 & 3.67 & 3.74 & 4.26 & 3.74 & 3.48 \\
\hline & UEvora_Eng & 4.12 & 4.38 & 4.23 & 3.88 & 3.77 & 3.73 & 3.65 & 3.92 & 3.46 & 3.23 \\
\hline & UEvora_AL & 4.09 & 4.36 & 3.73 & 3.91 & 3.64 & 3.45 & 4.00 & 3.82 & 4.00 & 3.45 \\
\hline \multirow{5}{*}{$\begin{array}{l}\text { University } \\
\text { of Lisbon }\end{array}$} & UL_CS & 4.22 & 4.25 & 4.07 & 3.90 & 3.86 & 3.81 & 4.02 & 4.12 & 3.78 & 3.76 \\
\hline & UL_CM & 4.21 & 4.07 & 4.14 & 4.00 & 3.43 & 3.64 & 3.50 & 3.79 & 3.36 & 3.36 \\
\hline & UL_CB & 4.38 & 4.54 & 4.46 & 4.08 & 4.31 & 3.69 & 4.00 & 3.54 & 3.77 & 3.77 \\
\hline & UL_Eng & 4.00 & 4.25 & 4.58 & 3.50 & 3.92 & 3.75 & 3.83 & 4.50 & 4.00 & 4.00 \\
\hline & UL_AL & 4.32 & 4.65 & 4.42 & 4.00 & 3.84 & 3.55 & 3.61 & 3.97 & 3.26 & 3.35 \\
\hline \multirow{5}{*}{$\begin{array}{l}\text { University } \\
\text { of Madeira }\end{array}$} & UMa_CS & 4.04 & 4.55 & 4.43 & 3.79 & 3.66 & 3.56 & 3.65 & 3.87 & 3.40 & 3.49 \\
\hline & UMa_CM & 3.80 & 4.40 & 4.30 & 4.20 & 3.30 & 4.20 & 4.10 & 4.10 & 4.10 & 3.60 \\
\hline & UMa_CB & 3.93 & 4.64 & 4.50 & 3.79 & 3.36 & 3.86 & 4.00 & 4.21 & 3.71 & 3.93 \\
\hline & UMa_Eng & 3.76 & 4.20 & 4.40 & 3.52 & 3.32 & 3.28 & 3.32 & 3.44 & 3.20 & 3.16 \\
\hline & UMa_AL & 4.00 & 3.33 & 4.17 & 3.92 & 3.67 & 3.83 & 3.75 & 3.75 & 3.75 & 3.75 \\
\hline \multirow{5}{*}{$\begin{array}{l}\text { University } \\
\text { of Minho }\end{array}$} & UMinho_CS & 4.36 & 4.34 & 4.43 & 3.98 & 3.81 & 3.70 & 3.75 & 4.13 & 3.74 & 3.75 \\
\hline & UMinho_CM & 4.45 & 4.36 & 4.36 & 4.00 & 3.91 & 3.73 & 4.00 & 4.27 & 3.91 & 3.91 \\
\hline & UMinho_CB & 3.92 & 4.50 & 4.67 & 3.75 & 3.75 & 4.25 & 3.83 & 4.33 & 3.67 & 4.08 \\
\hline & UMinho_Eng & 4.00 & 4.27 & 4.18 & 4.09 & 3.82 & 3.82 & 3.45 & 4.00 & 3.55 & 3.55 \\
\hline & UMinho_AL & 4.80 & 4.50 & 4.20 & 4.50 & 4.40 & 2.30 & 2.00 & 2.90 & 1.80 & 1.60 \\
\hline \multirow{5}{*}{$\begin{array}{c}\text { Nova } \\
\text { University } \\
\text { of Lisbon }\end{array}$} & UNL_CS & 3.82 & 4.32 & 4.50 & 4.05 & 3.91 & 3.82 & 3.82 & 4.14 & 3.82 & 3.82 \\
\hline & UNL_CM & 4.31 & 4.50 & 4.35 & 4.12 & 3.65 & 3.58 & 3.50 & 4.04 & 3.69 & 4.12 \\
\hline & UNL_CB & 4.15 & 4.64 & 4.51 & 3.77 & 4.21 & 3.79 & 3.87 & 4.41 & 3.62 & 4.08 \\
\hline & UNL_Eng & 4.06 & 4.28 & 4.31 & 3.98 & 3.97 & 3.67 & 3.87 & 4.28 & 3.83 & 4.05 \\
\hline & UNL_AL & 4.26 & 4.33 & 4.48 & 3.89 & 4.00 & 3.37 & 3.37 & 4.30 & 3.56 & 3.59 \\
\hline
\end{tabular}


Table 1 - Data for DEA analysis

\begin{tabular}{|c|c|c|c|c|c|c|c|c|c|c|c|}
\hline University & DMU & $\begin{array}{l}\text { Average } \\
\text { Expec. } \\
\text { Deman. } \\
\text { (MEE) }\end{array}$ & $\begin{array}{l}\text { Average } \\
\text { Expec. } \\
\text { Achieve. } \\
\text { (MER) }\end{array}$ & $\begin{array}{c}\text { Average } \\
\text { Expec. } \\
\text { Amb. } \\
\text { (MEA) }\end{array}$ & $\begin{array}{c}\text { Average } \\
\text { Expec. } \\
\text { Degree } \\
\text { (MEC) }\end{array}$ & $\begin{array}{l}\text { Average } \\
\text { Expec. } \\
\text { Univ. } \\
\text { (MEU) }\end{array}$ & $\begin{array}{l}\text { Average } \\
\text { Satis. } \\
\text { Deman. } \\
\text { (MSE) }\end{array}$ & $\begin{array}{l}\text { Average } \\
\text { Satis. } \\
\text { Achieve. } \\
\text { (MSR) }\end{array}$ & $\begin{array}{c}\text { Average } \\
\text { Satisf. } \\
\text { Amb. } \\
\text { (MSA) }\end{array}$ & $\begin{array}{l}\text { Average } \\
\text { Satisf. } \\
\text { Degree } \\
\text { (MSC) }\end{array}$ & $\begin{array}{c}\text { Average } \\
\text { Satisf. } \\
\text { Univ. } \\
\text { (MSU) }\end{array}$ \\
\hline \multirow{5}{*}{$\begin{array}{l}\text { Technical } \\
\text { University } \\
\text { of Lisbon }\end{array}$} & UTL_CS & 4.19 & 4.45 & 4.39 & 4.04 & 3.86 & 3.81 & 3.86 & 4.29 & 3.81 & 3.92 \\
\hline & UTL_CM & 4.20 & 4.90 & 4.50 & 4.00 & 3.90 & 3.30 & 3.30 & 3.90 & 3.40 & 3.90 \\
\hline & UTL_CB & 4.41 & 4.29 & 4.29 & 4.29 & 3.94 & 3.82 & 4.12 & 4.18 & 4.00 & 4.18 \\
\hline & UTL_Eng & 4.20 & 4.20 & 4.33 & 3.93 & 4.00 & 3.67 & 3.47 & 3.87 & 3.53 & 3.87 \\
\hline & UTL_AL & Excl. & - & -- & - & -- & -- & -- & -- & -- & -- \\
\hline \multirow{5}{*}{$\begin{array}{l}\text { University } \\
\text { of Trás- } \\
\text { os-Montes } \\
\text { and Alto } \\
\text { Douro }\end{array}$} & UTAD_CS & 3.92 & 4.00 & 3.92 & 3.77 & 3.38 & 3.46 & 3.69 & 3.92 & 3.08 & 3.31 \\
\hline & UTAD_CM & Excl. & -- & -- & - & - & - & -- & -- & - & -- \\
\hline & UTAD_CB & Excl. & -- & -- & -- & -- & - & -- & -- & - & - \\
\hline & UTAD_Eng & Excl. & -- & -- & -- & -- & - & -- & -- & -- & -- \\
\hline & UTAD_AL & 4.09 & 4.73 & 3.55 & 4.27 & 3.91 & 3.64 & 4.27 & 3.82 & 3.64 & 3.91 \\
\hline
\end{tabular}

OBS1: $C S=$ Ciências Sociais/Social Sciences; $\mathrm{CM}=$ Ciências Médicas/Medical Sciences; $\mathrm{CB}=$ Ciências Básicas/Basic Sciences; Eng=Engenharias/Engineering; AL=Artes and Letras/Arts and Letters Source: Research data

Table 1 first shows that seven DMUs were excluded from analysis. Despite the DEA analytical process only requiring DMU homogeneity (in this case, the faculties belonging to universities and governed by the same legislation and according to similar management principles) and the measurement of the same DMU inputs and outputs (in this case, student perceptions of their faculties as regards expectations and satisfaction), independent of the prevailing level of intensity, we decided to exclude a small number of DMUs from the study. This decision stems primarily from concerns about a DMU being considered efficient by a very small number of students. In the case of the DEA method, the sample size does not in itself prevent analysis as this is, after all, a non-statistical method and does not define absolute efficiencies but rather relative (comparative) positions.

With the reduction in the DMUs, the DMU's reason of $\mathrm{x}$ inputs and outputs (as already demonstrated) changed to 1.92. This reason result still remains above that established by Avkiran (1999) thus validating the data contained in table 1. Finally, Frontier Analyst software was applied in this analysis.

\subsection{General Analysis of DMU Efficiency}

This analysis considers all the inputs and outputs jointly. Thus, we sought to identify the level of DMU efficiency from the student perspective of the expectations and the levels of satisfaction they award their degrees and 
universities. This is one of the functions of DEA: gathering distinctive features into the same analytical process. The results are set out in table 2 and in graph 2.

Table 2 - DEA analysis results for all inputs and outputs

\begin{tabular}{|c|c|c|c|c|c|}
\hline DMU & Efficiency & DMU & Efficiency & DMU & Efficiency \\
\hline UAc_AL & 100.00 & UC_Eng & 97.28 & Uminho_AL & 65.53 \\
\hline UAc_CB & 100.00 & UEvora_AL & 100.00 & Uminho_CB & 100.00 \\
\hline UAc_CM & 100.00 & UEvora_CB & 100.00 & Uminho_CM & 98.45 \\
\hline UAc_CS & 95.49 & UEvora_CM & 100.00 & Uminho_CS & 94.82 \\
\hline UAc_Eng & 86.84 & UEvora_CS & 97.79 & Uminho_Eng & 95.91 \\
\hline UAlg_CM & 90.56 & UEvora_Eng & 93.37 & UNL_AL & 95.97 \\
\hline UAlg_CS & 100.00 & UL_AL & 91.07 & UNL_CB & 100.00 \\
\hline UAlg_Eng & 100.00 & UL_CB & 95.91 & UNL_CM & 100.00 \\
\hline UBI_AL & 100.00 & UL_CM & 92.75 & UNL_CS & 100.00 \\
\hline UBI_CB & 100.00 & UL_CS & 99.28 & UNL_Eng & 98.39 \\
\hline UBI_CM & 100.00 & UL_Eng & 100.00 & UTAD_AL & 100.00 \\
\hline UBI_CS & 100.00 & UMa_AL & 100.00 & UTAD_CS & 100.00 \\
\hline UBI_Eng & 93.43 & UMa_CB & 100.00 & UTL_CB & 100.00 \\
\hline UC_CB & 99.43 & UMa_CM & 100.00 & UTL_CM & 93.97 \\
\hline UC_CM & 97.27 & UMa_CS & 90.89 & UTL_CS & 98.16 \\
\hline UC_CS & 91.55 & UMa_Eng & 100.00 & UTL_Eng & 94.51 \\
\hline
\end{tabular}

Source: Research data

\section{Graph 2 - Summary of DEA analysis results for all inputs and outputs}

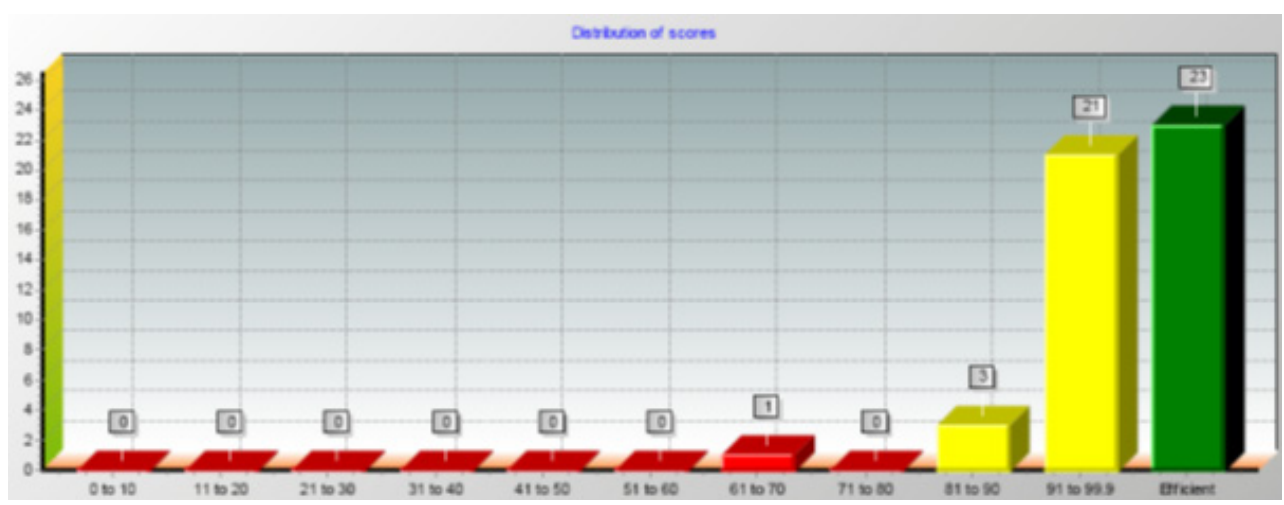

Source: Research data

Analysis of the data featured in table 2 and in graph 2 concludes that a fairly reasonable number of DMUs reported good levels of efficiency. There were 
23 DMUs that, across the set of inputs and outputs, returned the best relative efficiency levels as regards the other DMUs. This means that the relationship between expectation versus satisfaction at these DMU's is higher than at the other DMUs subject to analysis. Furthermore, this finding does display clues for best practices given how practically one half of the DMUs analysed proved efficient.

To boost the DEA power of discrimination, the process establishes a classification ranking of DMUs, based upon a comparison between efficient and inefficient DMUs. The purpose of this comparison is to show to an inefficient DMU what an efficient DMU looks like in a benchmarking style process. In this way, the more efficient DMUs cited as examples to be followed are discriminated in terms of their better relative performance results in terms of the differential between inputs and outputs. Graph 3 clarifies this comparison.

\section{Graph 3 - Classification of efficient DMUs}

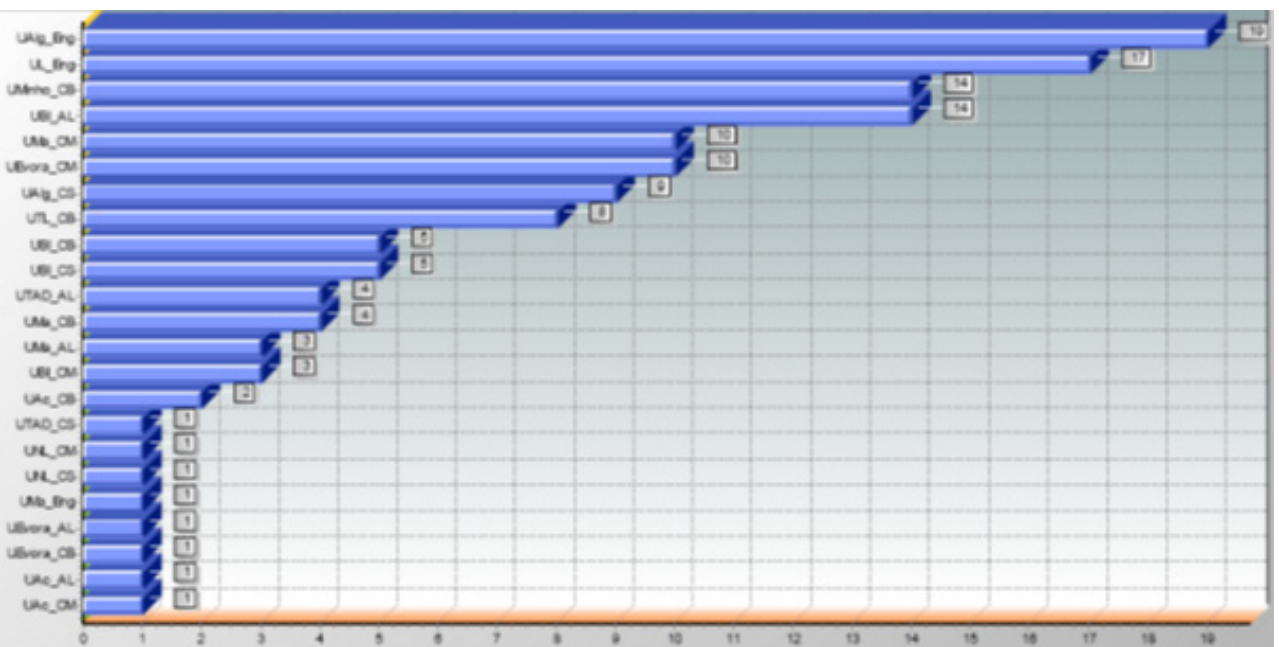

Source: Research data

In accordance with graph 3, we learn that the "UAlg_Eng” DMU received the highest efficiency ranking. Hence, this entity may serve as a benchmark for inefficient DMUs and may be deemed to have attained the best relationship between expectations and satisfaction when the specific evaluations of the degree and the university are jointly analysed. The "UL_Eng" DMU is close behind with the second highest relationship between inputs and outputs and onwards down through the DMU efficiency rankings.

Returning to table 2, we also need to focus on the inefficient DMUs. Of the 25 inefficient DMUs, 21 border on efficiency (over 91\%) and only 4 DMUs return low efficiency levels. One entity stands out from this group: the "UMinho_ 
AL" DMU with a $65.53 \%$ efficiency ranking. Observation of the average scores returned by this DMU (see table 1) leads to the conclusion that the efficiency rate is so low because the satisfaction of students falls far below the level of expectations and clearly requires measures to reverse the situation and primarily based on procedures and processes in effect at other high performing DMUs. Another exceptional situation is the "UAc_Eng" DMU. This DMU is a distant outlier in terms of efficiency and should also be the focus of remedial actions able to boost its efficiency through recourse to comparison with the "UAlg_Eng" DMU, for example, seeking to grasp the motives that lead students to declare their satisfaction levels are lower than their expectations (dissatisfaction).

In summary, the results demonstrated that a good majority of the DMUs turn in good performances, after all, 23 are positioned on the frontier of relative efficiency and another 21 are in close proximity. This may be taken as broadly suggesting Portuguese state universities have managed to correspond to general student expectations (with some exceptions), and provide satisfaction. However, this general analytical approach does not enable the identification of which DMUs stand out in terms of whichever specific factor (outputs). We therefore need to deepen our analysis and seek out the outstanding performances in specific situations. This analytical process is set out below.

\subsection{Analysis of core student demands}

This DEA analysis specifically incorporates the expectations and satisfaction as regards the level of study requirement, the university environment and self-achievement, with each respective factor analysed according to five different variables.

A summary of the DEA analysis results for the "the level of study requirement" variable is provided in table 3.

Taking into account that the level of study requirement is one of the core attributes shaping student perceptions in relation to the degree and their university (Mainardes, Alves and Domingues, 2009), this analysis sought to identify just which DMUs were best able to live up to the expectations of their students when compared with other DMUs (faculties). This does not refer to any absolute efficiency level but rather relative efficiency when a diverse samples of faculties (DMU's) are jointly subject to testing.

Analysing the data in table 3 finds that of the 48 DMUs, only between five and eleven attained efficiency in terms of their levels of study requirements. Therefore, we may propose that this variable requires attention at the majority of participant DMUs as students would generally seem to hold expectations as 
to the degree program's level of study requirements and these expectations are generally not being corresponded to (satisfied). In relation to the degree and the university, the positioning of the "UMa_CM" DMU, where students report that their expectations as regards the level of study requirement were bettered and they expressed more satisfaction than students at other DMUs. This DMU in particular proved able to attain greater efficiency in all the tests carried out and always out on the frontiers of efficiency. Other DMUs did also stand out, in particular "UAc_CM", “UBI_AL”, “UBI_CM", “UL_Eng” and "UMinho_CB”. These DMUs all returned relative efficiency levels ranked higher than other DMUs. We also found that a large proportion of DMUs attain efficiency rankings in excess of $81 \%$ and therefore the actions required to boost student satisfaction in relation to their expectations do not require major efforts to reach the efficiency frontier.

Table 3 - Summary of the DEA analysis results for "The level of study requirement" variable

\begin{tabular}{|l|l|l|l|l|l|}
\hline & Analysis 1 & Analysis 2 & Analysis 3 & Analysis 4 & Analysis 5 \\
\hline Inputs & MEE and MEC & MEE and MEC & MEE and MEU & MEE and MEU & MEE \\
\hline Outputs & MSE & MSC & MSE & MSU & MSE \\
\hline DMU & & & & & \\
\hline UAc_AL & 90.72 & 85.26 & 83.56 & 91.34 & 82.80 \\
\hline UAc_CB & 82.35 & 88.36 & 82.46 & 78.48 & 78.83 \\
\hline UAc_CM & 100.00 & 100.00 & 100.00 & 100.00 & 94.50 \\
\hline UAc_CS & 87.65 & 91.45 & 82.85 & 94.54 & 81.67 \\
\hline UAc_Eng & 79.76 & 86.10 & 80.37 & 80.20 & 75.04 \\
\hline UAlg_CM & 82.65 & 88.45 & 81.60 & 86.95 & 79.49 \\
\hline UAlg_CS & 89.88 & 97.71 & 89.88 & 98.81 & 87.13 \\
\hline UAlg_Eng & 86.35 & 93.96 & 86.35 & 100.00 & 82.66 \\
\hline UBI_AL & 100.00 & 100.00 & 95.69 & 100.00 & 90.09 \\
\hline UBI_CB & 97.80 & 93.09 & 94.74 & 92.33 & 83.22 \\
\hline UBI_CM & 92.71 & 95.79 & 100.00 & 100.00 & 83.52 \\
\hline UBI_CS & 90.35 & 99.24 & 90.78 & 96.80 & 86.49 \\
\hline UBI_Eng & 80.00 & 84.13 & 80.74 & 79.75 & 76.58 \\
\hline UC_CB & 90.35 & 92.01 & 90.35 & 98.39 & 81.59 \\
\hline UC_CM & 88.24 & 81.55 & 88.24 & 85.65 & 75.08 \\
\hline UC_CS & 80.94 & 75.34 & 80.94 & 79.43 & 69.80 \\
\hline UC_Eng & 87.76 & 93.36 & 87.76 & 96.45 & 81.17 \\
\hline UEvora_AL & 81.18 & 98.46 & 81.41 & 84.70 & 75.99 \\
\hline
\end{tabular}


Table 3-Summary of the DEA analysis results for "The level of study requirement" variable

\begin{tabular}{|c|c|c|c|c|c|}
\hline & Analysis 1 & Analysis 2 & Analysis 3 & Analysis 4 & Analysis 5 \\
\hline Inputs & MEE and MEC & MEE and MEC & MEE and MEU & MEE and MEU & MEE \\
\hline Outputs & MSE & MSC & MSE & MSU & MSE \\
\hline \multicolumn{6}{|l|}{ DMU } \\
\hline UEvora_CB & 91.52 & 93.00 & 87.06 & 86.91 & 80.45 \\
\hline UEvora_CM & 89.41 & 100.00 & 89.76 & 92.67 & 74.42 \\
\hline UEvora_CS & 87.29 & 91.00 & 85.65 & 82.78 & 79.79 \\
\hline UEvora_Eng & 87.76 & 85.25 & 87.76 & 78.37 & 81.56 \\
\hline UL_AL & 83.53 & 79.90 & 83.53 & 80.64 & 74.03 \\
\hline UL_CB & 86.82 & 92.11 & 86.82 & 90.27 & 75.90 \\
\hline UL_CM & 85.65 & 82.39 & 86.37 & 83.58 & 77.89 \\
\hline UL_CS & 89.65 & 93.03 & 89.65 & 90.64 & 81.34 \\
\hline UL_Eng & 100.00 & 100.00 & 88.24 & 96.85 & 84.46 \\
\hline UMa_AL & 90.12 & 92.31 & 90.31 & 92.22 & 86.26 \\
\hline UMa_CB & 90.82 & 91.79 & 91.76 & 100.00 & 88.49 \\
\hline UMa_CM & 100.00 & 100.00 & 100.00 & 100.00 & 100.00 \\
\hline UMa_CS & 83.76 & 84.08 & 83.96 & 85.74 & 79.39 \\
\hline UMa_Eng & 100.00 & 100.00 & 100.00 & 100.00 & 78.59 \\
\hline UMinho_AL & 54.12 & 43.90 & 54.12 & 38.28 & 43.17 \\
\hline UMinho_CB & 100.00 & 91.09 & 100.00 & 100.00 & 97.67 \\
\hline UMinho_CM & 87.76 & 95.78 & 87.76 & 93.68 & 75.51 \\
\hline UMinho_CS & 87.06 & 91.72 & 87.06 & 90.30 & 76.45 \\
\hline UMinho_Eng & 89.88 & 81.96 & 89.88 & 86.27 & 86.04 \\
\hline UNL_AL & 79.29 & 87.63 & 79.29 & 86.26 & 71.27 \\
\hline UNL_CB & 89.18 & 89.54 & 89.18 & 98.35 & 82.28 \\
\hline UNL_CM & 84.24 & 90.05 & 84.46 & 100.00 & 74.83 \\
\hline UNL_CS & 91.56 & 94.08 & 90.77 & 100.00 & 90.09 \\
\hline UNL_Eng & 86.35 & 94.05 & 86.35 & 97.89 & 81.44 \\
\hline UTAD_AL & 85.65 & 88.78 & 85.65 & 94.42 & 80.18 \\
\hline UTAD_CS & 81.41 & 76.31 & 82.21 & 84.53 & 79.52 \\
\hline UTL_CB & 89.88 & 97.56 & 89.88 & 100.00 & 78.04 \\
\hline UTL_CM & 77.65 & 83.38 & 77.65 & 93.89 & 70.79 \\
\hline UTL_CS & 89.65 & 93.30 & 89.65 & 94.55 & 81.92 \\
\hline UTL_Eng & 86.35 & 86.79 & 86.35 & 93.15 & 78.72 \\
\hline $\begin{array}{l}\text { Total efficient } \\
\text { DMUs }\end{array}$ & 6 & 6 & 5 & 11 & NT \\
\hline
\end{tabular}


Table 3 - Summary of the DEA analysis results for "The level of study requirement" variable

\begin{tabular}{|l|l|l|l|l|l|}
\hline & Analysis 1 & Analysis 2 & Analysis 3 & Analysis 4 & Analysis 5 \\
\hline Inputs & MEE and MEC & MEE and MEC & MEE and MEU & MEE and MEU & MEE \\
\hline Outputs & MSE & MSC & MSE & MSU & MSE \\
\hline DMU & & & & & \\
\hline $\begin{array}{l}\text { Total inefficient } \\
\text { DMUs 91\% to } \\
\text { 99\% }\end{array}$ & 4 & 21 & 3 & 17 & NT \\
\hline $\begin{array}{l}\text { Total inefficient } \\
\text { DMUs 81\% to } \\
\text { 90\% }\end{array}$ & 32 & 17 & 34 & 13 & NT \\
\hline $\begin{array}{l}\text { Total inefficient } \\
\text { DMUs 80\% or } \\
\text { less }\end{array}$ & 6 & 4 & 6 & 7 & NT \\
\hline Frontier DMUs & $\begin{array}{l}\text { UMa_CM and } \\
\text { UMinho_CB }\end{array}$ & $\begin{array}{l}\text { UMa_CM and } \\
\text { UL_Eng }\end{array}$ & UMa_CM & $\begin{array}{l}\text { UMinho_CB, } \\
\text { UMa_CB and } \\
\text { UBICM }\end{array}$ & NT \\
\hline
\end{tabular}

Source: Research data

The second variable studied was "self-achievement". We ran the same testing process as for the variable above. The results are displayed in table 4.

Table 4 - Summary of the DEA analysis results for the variable "Selfachievement"

\begin{tabular}{|l|l|l|l|l|l|}
\hline & Analysis 1 & Analysis 2 & Analysis 3 & Analysis 4 & Analysis 5 \\
\hline Inputs & MER and MEC & MER and MEC & MER and MEU & MER and MEU & MER \\
\hline Outputs & MSR & MSC & MSR & MSU & MSR \\
\hline DMU & & & & & \\
\hline UAc_AL & 90.92 & 86.18 & 86.70 & 89.75 & 81.33 \\
\hline UAc_CB & 96.77 & 88.17 & 95.90 & 77.48 & 77.20 \\
\hline UAc_CM & 93.79 & 97.56 & 93.79 & 81.58 & 81.03 \\
\hline UAc_CS & 92.12 & 89.73 & 89.97 & 90.49 & 75.56 \\
\hline UAc_Eng & 84.06 & 86.77 & 84.06 & 81.84 & 72.88 \\
\hline UAlg_CM & 84.84 & 88.82 & 83.20 & 87.25 & 73.04 \\
\hline UAlg_CS & 96.46 & 99.31 & 96.46 & 97.69 & 84.68 \\
\hline UAlg_Eng & 94.15 & 95.31 & 93.61 & 100.00 & 82.92 \\
\hline UBI_AL & 100.00 & 100.00 & 100.00 & 100.00 & 93.81 \\
\hline UBI_CB & 99.81 & 93.44 & 96.06 & 95.02 & 83.29 \\
\hline UBI_CM & 95.70 & 95.76 & 100.00 & 100.00 & 72.49 \\
\hline UBI_CS & 97.85 & 99.19 & 97.01 & 96.11 & 81.15 \\
\hline
\end{tabular}


Table 4 - Summary of the DEA analysis results for the variable "Selfachievement"

\begin{tabular}{|l|l|l|l|l|l|}
\hline & Analysis 1 & Analysis 2 & Analysis 3 & Analysis 4 & Analysis 5 \\
\hline Inputs & MER and MEC & MER and MEC & MER and MEU & MER and MEU & MER \\
\hline Outputs & MSR & MSC & MSR & MSU & MSR \\
\hline DMU & & & & & \\
\hline UBI_Eng & 83.34 & 85.09 & 83.70 & 81.67 & 72.90 \\
\hline UC_CB & 90.08 & 92.00 & 86.38 & 98.09 & 70.19 \\
\hline UC_CM & 82.61 & 81.55 & 81.63 & 85.65 & 65.21 \\
\hline UC_CS & 89.61 & 76.49 & 89.61 & 79.96 & 78.38 \\
\hline UC_Eng & 87.02 & 93.44 & 87.02 & 95.69 & 73.28 \\
\hline UEvora_AL & 95.69 & 98.54 & 95.44 & 84.81 & 81.19 \\
\hline UEvora_CB & 94.30 & 93.00 & 89.50 & 87.61 & 74.54 \\
\hline UEvora_CM & 100.00 & 100.00 & 100.00 & 92.67 & 79.28 \\
\hline UEvora_CS & 97.79 & 90.95 & 93.88 & 82.31 & 78.40 \\
\hline UEvora_Eng & 87.72 & 85.31 & 86.99 & 78.03 & 73.75 \\
\hline UL_AL & 85.20 & 79.88 & 84.68 & 80.54 & 68.70 \\
\hline UL_CB & 94.44 & 92.21 & 94.44 & 90.19 & 77.97 \\
\hline UL_CM & 84.96 & 84.34 & 84.96 & 87.39 & 76.10 \\
\hline UL_CS & 96.54 & 93.77 & 96.54 & 90.67 & 83.71 \\
\hline UL_Eng & 100.00 & 100.00 & 91.98 & 96.00 & 79.75 \\
\hline UMa_AL & 100.00 & 100.00 & 100.00 & 100.00 & 100.00 \\
\hline UMa_CB & 97.46 & 91.64 & 96.62 & 98.54 & 76.29 \\
\hline UMa_CM & 97.60 & 100.00 & 100.00 & 93.40 & 82.46 \\
\hline UMa_CS & 88.93 & 83.99 & 86.12 & 84.67 & 70.99 \\
\hline UMa_Eng & 100.00 & 100.00 & 81.15 & 83.94 & 69.95 \\
\hline UMinho_AL & 47.33 & 43.90 & 47.33 & 38.28 & 39.33 \\
\hline UMinho_CB & 93.65 & 90.80 & 90.40 & 98.53 & 75.12 \\
\hline UMinho_CM & 95.44 & 96.03 & 95.44 & 93.68 & 81.19 \\
\hline UMinho_CS & 89.58 & 92.01 & 89.58 & 90.46 & 76.47 \\
\hline UMinho_Eng & 82.76 & 82.67 & 82.76 & 85.81 & 71.50 \\
\hline UNL_AL & 80.87 & 87.80 & 80.55 & 85.89 & 68.88 \\
\hline UNL_CB & 94.58 & 89.49 & 90.84 & 97.61 & 73.81 \\
\hline UNL_CM & 82.83 & 90.16 & 82.83 & 100.00 & 68.83 \\
\hline UNL_CS & 91.36 & 93.99 & 91.36 & 91.52 & 78.25 \\
\hline UNL_Eng & 92.78 & 94.65 & 92.78 & 96.96 & 80.02 \\
\hline UTAD_AL & 99.70 & 88.78 & 99.70 & 93.68 & 79.89 \\
\hline UTAD_CS & 90.19 & 78.07 & 89.95 & 88.69 & 81.64 \\
\hline
\end{tabular}


Table 4 - Summary of the DEA analysis results for the variable "Selfachievement"

\begin{tabular}{|l|l|l|l|l|l|}
\hline & Analysis 1 & Analysis 2 & Analysis 3 & Analysis 4 & Analysis 5 \\
\hline Inputs & MER and MEC & MER and MEC & MER and MEU & MER and MEU & MER \\
\hline Outputs & MSR & MSC & MSR & MSU & MSR \\
\hline DMU & & & & & \\
\hline UTL_CB & 98.71 & 98.42 & 98.71 & 100.00 & 84.99 \\
\hline UTL_CM & 77.89 & 83.27 & 76.74 & 93.49 & 59.60 \\
\hline UTL_CS & 91.61 & 93.38 & 91.61 & 94.15 & 76.76 \\
\hline UTL_Eng & 83.58 & 87.85 & 83.58 & 93.21 & 73.11 \\
\hline $\begin{array}{l}\text { Total efficient } \\
\text { DMUs }\end{array}$ & 5 & 6 & 5 & 6 & NT \\
\hline $\begin{array}{l}\text { Total inefficient } \\
\text { DMUs 91\% to } \\
\text { 99\% }\end{array}$ & 23 & 19 & 18 & 18 & NT \\
\hline $\begin{array}{l}\text { Total inefficient } \\
\text { DMUs 81\% to } \\
\text { 90\% }\end{array}$ & 17 & 19 & 22 & 19 & NT \\
\hline $\begin{array}{l}\text { Total inefficient } \\
\text { DMUs 80\% or } \\
\text { less }\end{array}$ & 3 & 4 & 3 & UMa_AL, \\
\hline $\begin{array}{l}\text { Frontier DMUs } \\
\text { UM__AL_and }\end{array}$ & $\begin{array}{l}\text { UMa_AL, } \\
\text { UBI_AL and }\end{array}$ & $\begin{array}{l}\text { UMa_AL_Eng and } \\
\text { UL_Eng }\end{array}$ & UBI_CM and & NT \\
\hline
\end{tabular}

Source: Research data

The final variable tested was "university environment". As happened with the aforementioned variables, five analytical tests were run with the results presented in table 5 .

Table 5 - Summary of the DEA analysis results for the variable "University environment"

\begin{tabular}{|l|l|l|l|l|l|}
\hline & Analysis 1 & Analysis 2 & Analysis 3 & Analysis 4 & Analysis 5 \\
\hline Inputs & MEA and MEC & MEA and MEC & MEA and MEU & MEA and MEU & MEA \\
\hline Outputs & MSA & MSC & MSA & MSU & MSA \\
\hline DMU & & & & & \\
\hline UAc_AL & 84.70 & 83.35 & 88.07 & 85.34 & 77.57 \\
\hline UAc_CB & 100.00 & 89.72 & 100.00 & 83.70 & 100.00 \\
\hline UAc_CM & 91.77 & 96.85 & 94.66 & 80.37 & 84.51 \\
\hline UAc_CS & 89.41 & 89.99 & 94.08 & 91.09 & 81.88 \\
\hline
\end{tabular}


Table 5 - Summary of the DEA analysis results for the variable "University environment"

\begin{tabular}{|c|c|c|c|c|c|}
\hline & Analysis 1 & Analysis 2 & Analysis 3 & Analysis 4 & Analysis 5 \\
\hline Inputs & MEA and MEC & MEA and MEC & MEA and MEU & MEA and MEU & MEA \\
\hline Outputs & MSA & MSC & MSA & MSU & MSA \\
\hline \multicolumn{6}{|l|}{ DMU } \\
\hline UAc_Eng & 79.61 & 86.07 & 83.46 & 79.78 & 71.47 \\
\hline UAlg_CM & 85.71 & 88.27 & 88.79 & 85.59 & 78.93 \\
\hline UAlg_CS & 98.39 & 97.96 & 98.39 & 97.21 & 92.86 \\
\hline UAlg_Eng & 100.00 & 94.77 & 100.00 & 100.00 & 97.39 \\
\hline UBI_AL & 99.46 & 98.74 & 100.00 & 100.00 & 91.41 \\
\hline UBI_CB & 98.35 & 100.00 & 95.92 & 97.38 & 88.15 \\
\hline UBI_CM & 93.11 & 95.76 & 100.00 & 100.00 & 78.48 \\
\hline UBI_CS & 93.96 & 99.73 & 96.96 & 98.39 & 89.02 \\
\hline UBI_Eng & 88.62 & 84.16 & 93.40 & 80.62 & 80.71 \\
\hline UC_CB & 93.58 & 92.09 & 94.26 & 98.09 & 83.71 \\
\hline UC_CM & 95.82 & 82.01 & 95.82 & 85.83 & 90.09 \\
\hline UC_CS & 88.58 & 75.80 & 88.58 & 79.82 & 84.08 \\
\hline UC_Eng & 94.20 & 93.48 & 94.20 & 95.69 & 86.59 \\
\hline UEvora_AL & 100.00 & 100.00 & 100.00 & 100.00 & 92.26 \\
\hline UEvora_CB & 95.25 & 93.24 & 99.98 & 87.62 & 86.44 \\
\hline UEvora_CM & 95.56 & 100.00 & 98.75 & 92.67 & 84.21 \\
\hline UEvora_CS & 89.05 & 91.43 & 89.70 & 82.32 & 82.77 \\
\hline UEvora_Eng & 88.46 & 85.70 & 89.48 & 78.20 & 83.49 \\
\hline UL_AL & 88.84 & 80.03 & 89.40 & 80.54 & 80.92 \\
\hline UL_CB & 79.08 & 92.20 & 79.08 & 90.19 & 71.51 \\
\hline UL_CM & 85.87 & 82.94 & 89.85 & 90.16 & 82.47 \\
\hline UL_CS & 93.64 & 93.86 & 93.73 & 91.18 & 91.20 \\
\hline UL_Eng & 100.00 & 100.00 & 100.00 & 95.79 & 88.52 \\
\hline UMa_AL & 84.85 & 92.84 & 86.65 & 92.91 & 81.02 \\
\hline UMa_CB & 93.88 & 91.75 & 99.50 & 100.00 & 84.28 \\
\hline UMa_CM & 92.24 & 100.00 & 98.11 & 97.96 & 85.90 \\
\hline UMa_CS & 86.57 & 84.19 & 88.73 & 84.67 & 78.70 \\
\hline UMa_Eng & 100.00 & 100.00 & 81.89 & 83.43 & 70.43 \\
\hline UMinho_AL & 65.53 & 44.09 & 65.53 & 38.47 & 62.21 \\
\hline UMinho_CB & 96.22 & 90.80 & 97.79 & 98.53 & 83.53 \\
\hline UMinho_CM & 95.81 & 96.08 & 95.81 & 93.68 & 88.23 \\
\hline UMinho_CS & 92.38 & 91.87 & 93.25 & 90.29 & 83.99 \\
\hline UMinho_Eng & 90.47 & 82.30 & 91.01 & 85.86 & 86.21 \\
\hline UNL_AL & 95.97 & 87.71 & 95.97 & 85.89 & 86.47 \\
\hline
\end{tabular}


Table 5-Summary of the DEA analysis results for the variable "University environment"

\begin{tabular}{|c|c|c|c|c|c|}
\hline & Analysis 1 & Analysis 2 & Analysis 3 & Analysis 4 & Analysis 5 \\
\hline Inputs & MEA and MEC & MEA and MEC & MEA and MEU & MEA and MEU & MEA \\
\hline Outputs & MSA & MSC & MSA & MSU & MSA \\
\hline \multicolumn{6}{|l|}{ DMU } \\
\hline UNL_CB & 98.30 & 89.59 & 98.30 & 97.61 & 88.09 \\
\hline UNL_CM & 90.69 & 90.23 & 92.94 & 100.00 & 83.67 \\
\hline UNL_CS & 92.32 & 93.48 & 92.34 & 91.52 & 82.88 \\
\hline UNL_Eng & 96.24 & 94.29 & 96.24 & 96.89 & 89.46 \\
\hline UTAD_AL & 100.00 & 100.00 & 100.00 & 100.00 & 96.94 \\
\hline UTAD_CS & 100.00 & 100.00 & 100.00 & 100.00 & 90.09 \\
\hline UTL_CB & 94.08 & 97.60 & 94.08 & 100.00 & 87.78 \\
\hline UTL_CM & 86.97 & 83.37 & 87.07 & 93.49 & 78.08 \\
\hline UTL_CS & 96.13 & 93.42 & 96.52 & 94.15 & 88.04 \\
\hline UTL_Eng & 86.95 & 87.06 & 86.95 & 92.58 & 80.52 \\
\hline $\begin{array}{l}\text { Total efficient } \\
\text { DMUs }\end{array}$ & 7 & 8 & 8 & 9 & NT \\
\hline $\begin{array}{l}\text { Total inefficient } \\
\text { DMUs } 91 \% \text { to } \\
99 \%\end{array}$ & 23 & 20 & 25 & 19 & NT \\
\hline $\begin{array}{l}\text { Total inefficient } \\
\text { DMUs } 81 \% \text { to } \\
90 \%\end{array}$ & 15 & 17 & 13 & 13 & NT \\
\hline $\begin{array}{l}\text { Total inefficient } \\
\text { DMUs } 80 \% \text { or } \\
\text { less }\end{array}$ & 3 & 3 & 2 & 7 & NT \\
\hline Frontier DMUs & $\begin{array}{l}\text { UAc_CB, } \\
\text { UAlg_Eng and } \\
\text { UL_Eng }\end{array}$ & $\begin{array}{l}\text { UEvora_AL and } \\
\text { UL_Eng }\end{array}$ & $\begin{array}{l}\text { UAC_CB, } \\
\text { UBI_AL and } \\
\text { UBI_CM }\end{array}$ & $\begin{array}{l}\text { UTAD_AL, } \\
\text { UAlg_Eng, } \\
\text { UNL_CM and } \\
\text { UBI_CM }\end{array}$ & NT \\
\hline
\end{tabular}

Source: Research data

On analysis of the university environment (table 5) variable, we found this factor gained the highest level of results. This was the variable that gained greatest student satisfaction when compared with their respective expectations. In particular, we may identify the relationship between student expectations and satisfaction at the "UAc_CB" and "UEvora_AL"DMUs. These two DMUs return the best results in terms of relative efficiency despite neither of the pair (nor the other 46 DMU's) gaining a 100\% efficiency ranking across all tests. Hence, we may state that these DMUs seem to better meet student expectations when compared with peer DMUs. The other well-ranked DMUs were: "UAlg_Eng”, "UBI_AL", 
“UBI_CB", UBI_CM", “UL_Eng”, “UTAD_AL” and "UTAD_CS”. Any such faculty might serve as a benchmark for the other DMUs.

In accordance with the importance of the university environment as a factor in the attraction, retention and relationship with students, any DMU reporting lower efficiency results requires specific attention by their managers. They may act according to a study of the processes, procedures and actions ongoing at those DMUs displaying efficiency as there is clear worth in enhancing the university environment given its importance to student learning as well as their sustained presence on the course of study and at the university (Mainardes, Alves and Domingues, 2009).

Finally, another factor worth highlighting is the incidence of DMUs who gained good performance results in the analysis of specific variables but did not achieve this in the general analysis. They should analyse their performance in relation to other variables as it would seem that while they are meeting student expectations in these terms (satisfaction), there may be other drivers of dissatisfaction influencing overall satisfaction levels but deriving from other factors requiring study and research.

\section{CONCLUSIONS AND RECOMMENDATIONS}

On completion of this stage, with its objective of evaluating the performance of Portuguese state universities based upon the levels of expectation and satisfaction held by their students and through recourse to the DEA method, we obtained results identifying just which faculties attained good relationships between student expectations and satisfaction levels. This may, and according to the sufficient management practices in place at the aforementioned faculties, enable the efficiency rates of entities returning higher levels of inefficiency to be acted on. As commented at the outset, the management literature on universities rarely demonstrates university performance in terms of student perceptions and hence this represents a core contribution of this research.

Based upon comparative analysis of the various faculties belonging to the eleven universities studied, we gained a relative efficiency ranking of these faculties, referred to as DMUs, from the perspectives of their students. We made our analytical approach at the faculty level (and not taking the universities as a whole) as universities represent a group of faculties with many of the management processes and techniques varying between the different faculties at the same university (Weick, 1976).

Therefore, in accordance with the results obtained, we may conclude that university scale is no guarantee of efficiency. Hence, irrespective of size, 
efficiency in satisfying student expectations is achievable just as university scale cannot serve in justification of explaining away the relative inefficiency of the organisation. Furthermore, for those DMUs ranked as among the more efficient in large percentages of their aspects, this does not exactly mean that they should stick to the working practices and procedures in effect but should see the ranking as a stimulus for constantly developing and seeking out improvements. They should especially focus on means of boosting student satisfaction levels and particularly through deepening the relationship with this stakeholder in order to better understand their expectations and engage in actions designed to satisfy and exceed these expectations (Arnett, German and Hunt, 2003).

In cases of inefficient DMUs, they should undertake a profound review and evaluation of their realities as well as comparative analysis with efficient DMUs, which may serve as benchmarks and points of reference for improving efficiency levels (Shaw, 2009) and provide insights into grasping the reasons for their failure to meet and exceed student expectations. Such actions may not necessarily require high resource inputs as simple measures may prove to cause the difference for the subsequent positioning on or under the efficiency border. However, the focus should certainly be placed on satisfying students (Jongbloed, Enders and Salerno, 2008).

Another finding of this study is that only satisfying the expectations related to specific aspects does not prove sufficient for guaranteeing overall student satisfaction. The analytical findings show how some DMUs are efficient in handling expectations on certain factors but do not attain efficiency levels in the overall student vision. Therefore, the replication of this analysis with other variables might serve to indicate sources of student dissatisfaction preventing a DMU from reaching efficiency in the general analysis.

Furthermore, we also find that the same university may host both efficient faculties (on the efficiency frontier) and inefficient faculties (distant from the efficiency frontier). As Weick (1976) defends, universities are systems with very weakly linked units, which result in distortions across organisations. In such cases, and undoubtedly, universities are not homogenous and integrated organisations working according to uniform standards and patterns and instead are a set of independent units with distinctive and different performance levels. Therefore, contrary to pooling forces and growing in partnership, some universities do not follow shared and common strategies but end up with overlapping efforts wasting their core resources, with the university's multidisciplinary capacities preventing singular objectives (Galbraith, 2003).

As regards analysis of the specific variables, we would propose several findings. Our first observation is that a majority of students reported that they 
were expecting more challenging study programs whilst only a handful of DMUs achieved efficiency levels with the smaller scale universities turning in better performances. However, this did not derive from their challenging standards but rather because the expectations of students were lower from the outset. On the other hand, a majority of faculties are not far from meeting student expectations and verge onto the efficiency frontier. Furthermore, this same finding holds for the case of the self-achievement variable.

Finally, as regards the university environment, a larger number of DMUs were classified as efficient. Once again, the environments prevailing at smaller universities gained a higher ranking from students, which may be explained either by a preference for smaller scale surroundings or a greater sense of student belonging to less pluralistic environments. In addition, we also encounter universities where one faculty's environment is perceived as fairly efficient while that of another faculty at the same university is ranked as inefficient. This may be related to the degree program that may shape the perceptions of students as regards the broader university environment.

As the main recommendation stemming from the completion of this research project, we would emphasise how the analysis of efficiency through recourse to DEA does measure the university's performance from the perspective of its students. According to Zhu (2009), this type of analysis may prove useful to universities in terms of:

- Allocating resources within the university (striving for efficiency at inefficient units);

- Identification of best practices;

- Definition of targets to be attained by each unit;

- Monitoring changes in efficiency over the course of time;

- Identification of units deserving recognition for their good performance levels;

- Planning future positioning and investments.

Therefore, this analytical approach proves a useful tool for ascertaining the objectives of a university. Hence, undertaking this type of analysis, deeming expectation and satisfaction levels as the inputs and outputs is feasible and serves to identify, for example, those faculties and/or universities that are efficient at their teaching mission but inefficient in terms of their research goals.

As limitations to the study carried out, we should refer to the methodology applied and especially in terms of its non-measurement of absolute efficiency. Thus, a DMU may achieve relative efficiency (better performance when compared with other DMUs), but its performance level may still not attain the proposed

442 - RBPAE - v. 32, n. 2, p. 421 - 447 mai./ago. 2016 
objectives (effectiveness). The DEA methodology cannot incorporate this facet and is a limitation that needs taking into account in this analysis. Therefore, other methodologies might be applied to accompany and complement the analysis and enabling conclusions as to whether the performance of a unit is above or below that expected. Another limitation is the number of DMUs that the methodology requires. For comparisons between the low number of units (as would have been the case for analysis of the eleven universities as a whole), the methodology does not discriminate well between the differences existing at DMUs and correspondingly requiring a relatively high number of units for analysis. In this way, expanding the research universe would contribute towards positioning Portuguese state universities in terms of their efficiency within the context of Portuguese higher education. Despite limitations, the methodology presented does prove a valid and insightful means of demonstrating student perceptions of Portuguese state university faculties and their degree programs.

\section{REFERENCES}

Alves, H., \& Raposo, M. (2007). "Student Satisfaction Index in Portuguese public higher education”, The Service Industries Journal, 27, 6, 795-808.

Anderson, E., \& Fornell, C. (2000). "The Customer Satisfaction Index as a leading indicator". In: Swartz, T. and Iacobucci, D. (Eds.), Handbook of service marketing and management. London: Sage Publications, 255-267.

Arnett, D., German, S., \& Hunt, S. (2003). "The identity salience model of relationship marketing success: the case of nonprofit marketing", Journal of Marketing, 67, 1, 89-105.

Avkiran, N. (1999). "An application reference for data envelopment analysis in branch banking: helping the novice researcher", International Journal of Bank Marketing, 17, 5, 206-220.

Avkiran, N. (2001). "Investigating technical and scale efficiencies of Australian universities through data envelopment analysis", Socio-Economic Planning Sciences, 35, 1, 57-80.

Banker, R., \& Maindiratta, A. (1986). "Piecewise loglinear estimation of efficient production surfaces”, Management Science, 32,1,126-135. 
Banker, R., \& Morey, R. (1986). "Efficiency analysis for exogenously fixed inputs and outputs”, Operations Research, 34, 4, 513-521.

Banker, R., Charnes, A., \& Cooper, W. (1984). "Some models for estimating technical and scale inefficiencies in data envelopment analysis", Management Science, 30, 9, 1078-1092.

Charnes, A., Cooper, W., \& Rodhes (1978). "Measuring the efficiency of decision marking units", European Operational Research, 2, 6, 429-444.

Charnes, A., Cooper, W., Lewin, A., \& Seiford, L. (1994). Data envelopment analysis: theory, methodology and application. Boston: Kluwer Academic Publishers.

Cooper, W., Seiford, L., \& Tone, K. (2000). Data envelopment analysis: a comprehensive text with models, applications, references and DEA-Solver software. Boston: Kluwer Academic Publishers.

Cooper, W., Seiford, L., \& Tone, K. (2006). Introduction to data envelopment analysis and its uses. New York: Springer.

Epstein, M., \& Henderson, J. (1989). "Data envelopment analysis for managerial control and diagnosis”, Decision Sciences, 20,1, 90-119.

Fandel, G. (2007). "On the performance of universities in North RhineWestphalia, Germany government's redistribution of funds judged using DEA efficiency measures", European Journal of Operational Research, 176, 1, 521 533.

Farrell, M. (1957). "The measurement of productive efficiency", Journal of the Royal Statistical Society, series A, 20, 3, 253-281.

Farrell, M., \& Fieldhouse, M. (1962). "Estimating efficient production frontiers under increasing returns to scale. Journal of the Royal Statistical Society, series A, $125,3,252-267$.

Galbraith, K. (2003). "Towards quality private higher education in Central and Eastern Europe", Higher Education in Europe, 28, 4, 539-559.

444 - RBPAE - v. 32, n. 2, p. 421 - 447 mai./ago. 2016 
Garver, M. (2003). "Best practices in identifying customer-driven improvement opportunities”, Industrial Marketing Management, 32, 1, 455-466.

Grönroos, C. (2000). "Service reflections: service marketing comes of age". In: Swartz, T. and Iacobucci, D. (Eds.), Handbook of service marketing and management. London: Sage Publications, 13-16.

Grönroos, C., \& Ojasalo, K. (2004). "Service productivity: towards a conceptualization of the transformation of inputs into economic results in services”, Journal of Business Research, 57, 1, 414-423.

Hair Jr., J., Babin, B., Money, A., \& Samouel, P. (2003). Essentials of business research methods. New Jersey: John Wiley \& Sons.

Johnes, J. (2006). "Data envelopment analysis and its application to the measurement of efficiency in higher education", Economics of Education Review, 25, 1, 273-288.

Jongbloed, B., Enders, J., \& Salerno, C. (2008). "Higher education and its communities: interconnections, interdependencies and research agenda", Higher Education, 56, 303-324.

Kantabutra, S., \& Tang, J. (2010). "Efficiency analysis of public universities in Thailand", Tertiary Education and Management, 16, 1, 15-33.

Kirkley, J., Färe, R., Grosskopf, S., McConnell, K., Strand, I., \& Squires, D. (2001). "Assessing capacity in fisheries when data are limited", North American Journal of Fisheries Management, 21, 3, 482-497.

Kotler, P. (2003). Marketing management: analysis, planning, implementation and control. Englewood Cliffs, New Jersey: Prentice Hall.

Mainardes, E., Alves, H., \& Domingues, M. (2009). "Which factors are important to attract students for undergraduate administration courses?", The FedUni Journal of Higher Education, 4, 1, 84-102.

Sarrico, C., \& Dyson, R. (2000). "Using DEA for planning in UK universities: an institutional perspective", Journal of the Operational Research Society, 51, 7, 789-800. 
Scheerens, J. (2000). Improving school effectiveness. Paris: UNESCO.

Shaw, E.(2009). "A general theory of systems performance criteria", International Journal of General Systems, 38, 8, 851-869.

Vargo, S., \& Lusch, R. (2004). "Evolving to a new dominant logic for marketing", Journal of Marketing, 68, 1, 1-17.

Weick, K. ( $\neg 1976)$. "Educational organizations as loosely coupled systems". Administrative Science Quarterly, 21, 1-19.

Youn, J., \& Park, K. (2009). "University development models and efficiency analysis", Journal of Service Science, 1, 1, 9-30.

Zhu, J. (2009). Quantitative models for performance evaluation and benchmarking: data envelopment analysis with spreadsheets. 2 ed. New York: Springer.

EMERSON WAGNER MAINARDES é Ph.D. em Gestão (UBI, Covilhã / Portugal, 2010), Professor Associado da FUCAPE Business School, Vitória/ES, Brasil. Sua formação acadêmica inclui um mestrado em Gestão de Marketing (FURB, Blumenau/SC/Brasil, 2007), especialização em Gestão e graduação em Engenharia Elétrica. Professor e pesquisador em Gestão e Marketing e bolsista de investigação na NECE (Núcleo de Estudos em Ciências Empresariais). Especialidade: Inovação e Marketing.E-mail emerson@fucape.br; emainardes@ kesservice.com.br

HELENAALVES é Professora Adjunta na Universidade da Beira Interior, Portugal. Possui $\mathrm{PhD}$ em Gestão e tem feito pesquisa na área de marketing educacional. Editora da Revista International Review on Public and Non Profit Marketing. Especialidade: marketing educacional, Serviços de Marketing e Marketing de Relacionamento. E-mail: halves@ubi.pt

MÁRIO RAPOSO é PhD em Gestão, Professor Catedrático do Departamento de Gestão e Economia na University of Beira Interior, onde é coordenador científico da Unidade de Investigação em Ciências Empresariais e do Programa de Doutoramento em Marketing e Estratégia. Leciona disciplinas na área de 
Marketing, Estratégia e Empreendedorismo. No passado recente, foi vice-reitor da Universidade e chefe do Gabinete de Ligação. Foi presidente de conferências internacionais e coordenou estudos com impacto significativo. Atualmente é vice-presidente do ECSB - European Council of Small Business, em Portugal. E-mail: mraposo@ubi.pt

Recebido em maio de 2016

Aprovado em maio de 2016 